\title{
Corrective shoeing in horses: Analysis of the adaptation period to the new condition imposed ${ }^{1}$
}

INDEXING TERMS: Corrective shoeing, horse, locomotion analysis.

RESUMO.- [Ferrageamento corretivo em equinos: análise do período de adaptação à nova condição imposta.] $\mathrm{O}$ ferrageamento corretivo é um método comumente utilizado para alterar o padrão do andamento dos animais, assim como na terapêutica de diversas afecções do sistema locomotor dos equinos. No entanto, não existem, até o momento, estudos científicos que revelem o período de adaptação do andamento dos animais a este tipo de intervenção. 0 objetivo deste estudo foi avaliar o período de adaptação à ferraduras com elevação em seis graus da pinça ou talões em equinos caminhando em esteira rolante. 0 período de adaptação à ferradura foi avaliado nos tempos 0 , 48 e 96 horas após cada tipo de ferrageamento proposto. Os animais foram gravados caminhando em esteira

\footnotetext{
${ }^{1}$ Received on November 21, 2011.

Accepted for publication on July 4, 2012.

${ }^{2}$ Departamento de Morfologia e Fisiologia Animal, Faculdade de Ciências Agrárias e Veterinárias (FCAV), Universidade Estadual Paulista (Unesp), Via de Acesso Prof. Dr. Paulo Donato Castellane s/n, Jaboticabal, SP 14884-900, Brazil. *Corresponding author: raquel_albernaz@hotmail.com

${ }^{3}$ Departamento de Clínica e Cirurgia Veterinária, FCAV-Unesp, Jaboticabal, SP.
}

rolante. 0 comprimento da passada e a análise qualitativa do andamento foram realizados com o auxílio do programa Dvideow. 0 nível de significância adotado foi de $5 \%$. No presente estudo, não houve diferença significativa entre os dias avaliados, a elevação em seis graus da pinça ou talões não gerou desconforto durante a passada, portanto, os animais podem retornar às atividades regulares de exercício e treinamento imediatamente após o ferrageamento.

TERMOS DE INDEXAÇÃO: Ferrageamento corretivo, equino, análise do andamento.

\section{INTRODUCTION}

Locomotion is defined as a coordinated movement, which due to its sequence and synchronism, produces forward motion. Each animal species has a characteristic locomotion, and horses are particularly versatile due to the variety of movements that they can exhibit naturally (Barrey 2001, Clayton 2004).

Each type of locomotion has a characteristic ground contact sequence during the gait and coordinated movement between the involved limbs (Clayton 2004). It is possible to classify horse locomotion into two, three, or four 
beats, which correspond to each impact of the hoof on the ground (Adams 1994, Clayton 2004).

The walk is a four-beat gait with a considerable overlap of the phases of support between the limbs. The walk is the slowest type of locomotion, but it is the most complex due to the variability of the position and the timing irregularity between the limbs. (Clayton 2004). The representation of the sequence of support on the ground determines the diagram for each gait (Back 2001) (Fig.1).
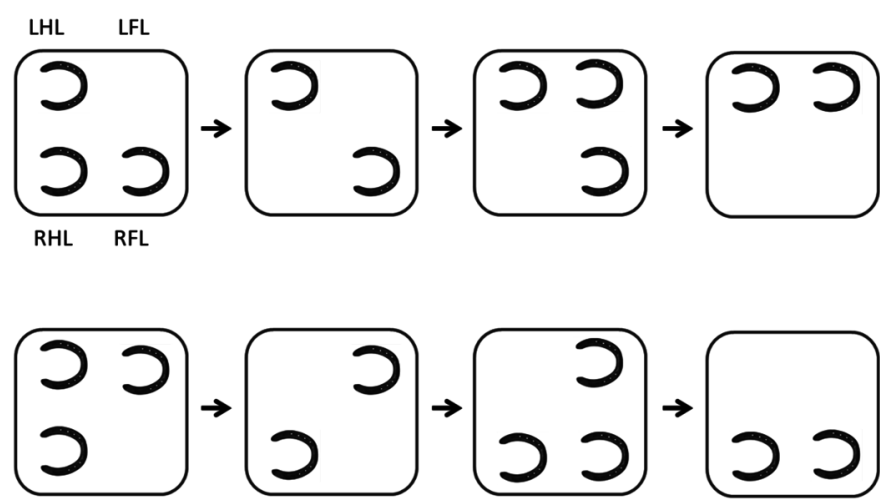

Fig.1. Diagram of walking. The support phase is represented by the shoe, and the lacunae in white represent the suspension phase. Left hind limb (LHL), left front limb (LFL), right hind limb (RHL) and right front limb (RFL).

Corrective shoeing is a method commonly used to alter the locomotion pattern of animals or as therapy for various disorders of the locomotive system in horses (Chateau et al. 2006). During locomotion, each step involves forces that overload or offer resistance to the musculoskeletal system (Back 2001). The hoof transfers force from the locomotive system to the ground. Along with its primary functions of supporting, protecting, and dissipating the impact, the hoof can be considered an extension of the distal phalanx. Therefore, the hoof serves as a lever or rigid structure and is used as a fixed point to multiply the mechanical force that can be applied to another structure, the distal interphalangeal joint (Parks 2003, O'Grady \& Poupard 2003, O'Grady 2008).

Trimming the hoof and shoeing influence both the external and internal structures of the hoof. The angle formed between the wall of the hoof and the ground can be modified to alter the locomotive pattern, improve the athletic performance, and to treat some types of lameness (Eliashar et al. 2002).

Shoes are commonly used to improve the athletic performance of racehorses. To supposedly extend the time of takeoff and increase the length of the step, the practice of shoeing to lower the heel and extend the toe is common. This modification produces a more acute angle for the wall of the hoof (Leach 1983). Nevertheless, there have been no studies to date that look at the adaptation period of the animal's locomotion to this type of intervention.

Therefore, this study tests the hypothesis that elevating the toe or heel by six degrees generates some discomfort during locomotion and that horses need time to adapt before returning to a regular exercise or training routine. Thus, the objective of this study was to evaluate the shoe adaptation period in horses walking on a treadmill after elevating the toes or heels by six degrees.

\section{MATERIALS AND METHODS}

The study was conducted at the Laboratory for the Physiology of Horse Exercise and Pharmacology (LAFEQ), Department of Morphology and Animal Physiology, School of Veterinary and Agrarian Sciences of the Paulista State University "Júlio de Mesquita Filho" (Unesp), Campus Jaboticabal, SP, Brazil. The present study was approved by the Committee on Ethics and Well Being (CEBEA) of this institution ${ }^{4}$.

For this trial, seven clinically healthy Arabian horses, including five males and two females, that belong to the experimental herd of the Department of Veterinary and Agrarian Sciences were used. The average age of the horses was $7 \pm 1.5$ years. Over the course of the experimental period, the horses received 3.0 $\mathrm{kg}$ of concentrated feed per day, as well as water and hay ad libitum.

The horses had been adapted to exercise on a treadmill in a previous trial performed by Silva et al. (2009). All of the animals underwent general and specialized clinical exams, with an emphasis on the locomotive system, using the evaluation methodology proposed by Ross (2003). All of the evaluated animals were considered healthy and able to participate in this study. The animals selected after examining the locomotive system had their hooves trimmed by one experienced professional. The angle of the hoof wall was preserved for each animal, and the average angle after the procedure was $50.4 \pm 1.81^{\circ}$ for left forelimb and $49.5 \pm 1.60^{\circ}$ for right forelimb. After this procedure, the hooves of forelimbs were set with special shoes including flat, elevated toe and elevated heel shoes.

The horses were randomly distributed into two groups, A and $B$, which comprised four and three animals, respectively. The trial consisted of nine videographic assessments, spread out over 19 days. For each type of shoes used (flat, elevated toe and elevated heel), all animals were evaluated immediately after shoeing and after $48 \mathrm{~h}$ and $96 \mathrm{~h}$ subsequent to this procedure (session one, two and three), aiming to observe the adaptation period of this type of intervention.

Between recording sessions, horses remained in individual stalls and were released into a grass paddock for one hour of free exercise in the morning and one hour in the afternoon. At the end of the third recording session the shoes were removed and the animals had a rest period of two days among shoeing procedures where they could walk or exercise in a grass paddock.

At the beginning of the trial both groups were recorded in a lateral view on a treadmill walking at $1.4 \mathrm{~m} / \mathrm{s}$ using flat standard shoes and were evaluated immediately after shoeing and after $48 \mathrm{~h}$ and $96 \mathrm{~h}$ after this procedure, as previously described. After this procedure, animals from group A used shoes with an elevated toe, and animals from group B used shoes with an elevated heel. Again, animals were recorded instantly following shoeing and past $48 \mathrm{~h}$ and $96 \mathrm{~h}$.

For the last three sessions, the animals from group A used shoes with an elevated heel, and the animals from group B used shoes with an elevated toe (Fig.2).

We opted to use shoes elevated six degrees, as suggested by Chateau et al. (2004). A protractor with a magnetic base was used to confirm the correct angle for each type of shoe. All of the shoes used in this study had an incline of six degrees relative to the ground.

\footnotetext{
${ }^{4}$ Protocol 028057-08.
} 

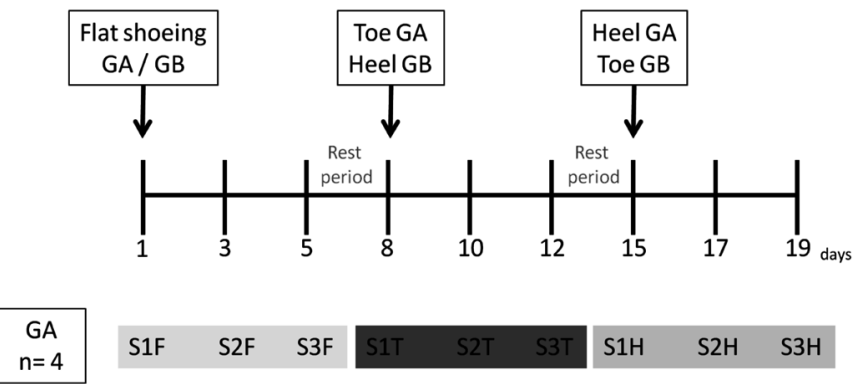

$G B$
$n=3$

S1F S2F S3F $\quad$ S1H S2H S3H

Fig. 2. Timeline of events showing phases of the trial. (GA = Group $\mathrm{A} ; \mathrm{GB}=$ Group $\mathrm{B} ; \mathrm{S}=$ Session; F = Flat shoe; $\mathrm{T}=$ Toe; $\mathrm{H}=$ Heels).

Digital video tapes ${ }^{5}$ were used for recording. The captured images were exported to the computer using the image capture program $\mathrm{AMCap}^{6}$ (capture application sample) and converted to files in avi format. From files obtained through the AMCap program, the images were segmented into the interval of interest.

Stride length was obtained by the ratio of number of fields per step, acquired using Dvideow software (Barros et al. 1999, Figueroa et al. 2003) for the videographic camera capture frequency $(60 \mathrm{~Hz})$. The result was multiplied by treadmill speed $(1.4 \mathrm{~m} / \mathrm{s})$. A single step included a complete motion cycle of a limb, in this case, the left forelimb. Also a qualitative analysis was carried out by counting the forelimbs stumbling in the first thirty steps performed on the treadmill.

The data were subjected to tests of assumptions for the normality of errors (Kolmogorov-Smirnov test) and homogeneity of variances (homoscedasticity) (Levene's test) with the level of significance set at $5 \%$. The variables were then subjected to an analysis of variance ( $F$ test). If a difference was detected $(p<0.05)$, then Tukey's test was used to compare the means between groups and the times evaluated within each treatment. For all of the tests, the level of significance adopted was $5 \%$.

\section{RESULTS AND DISCUSSION}

In the present study, a treadmill controlled the velocity and environmental conditions and created greater uniformity and standardization of movement. According to Bertone (2003), the treadmill is a useful tool for analyses in controlled conditions at constant velocities. The treadmill also allowed the steps to be recorded over time without moving the recording camera. The analysis was performed at 0,48 , and 96 hours after each type of shoeing. The quantitative (stride length) and qualitative results (forelimb stumbling) are presented in Tables 1 and 2 .

According to Clayton (2004) the stride length is calculated by measuring the separation of successive ground contacts of the same hoof and represents the displacement of the horse's center of mass in the direction of moving during a complete stride. In the present study the left forelimb were used to measure this variable and the results are in accordance with Barrey (2001) which states that the stride length in health horses, walking at $1.2 \mathrm{~m} / \mathrm{s}$ to $1.8 \mathrm{~m} / \mathrm{s}$ should range from $1.5 \mathrm{~m}$ to $1.9 \mathrm{~m}$.

\footnotetext{
${ }^{5}$ Tape MiniDV Panasonic 70,4m 60min LinearPlus.

${ }^{6}$ AMCap Microsoft Corporation.
}

Table 1. Average (mean \pm standard deviation) of stride length (m) according to the evaluation times (hours) in the analysis of the shoeing adaptation period in horses subjected to three different shoeing conditions

\begin{tabular}{cccc}
\hline Evaluation times & \multicolumn{3}{c}{ Shoeing condition } \\
\cline { 2 - 4 } & Flat standard & Toe elevation & Heel elevation \\
\cline { 2 - 4 } & & Stride length \\
\hline $0 \mathrm{~h}$ & $1.58^{\mathrm{a}} \pm 0.07$ & $1.56^{\mathrm{a}} \pm 0.05$ & $1.62^{\mathrm{a}} \pm 0.08$ \\
$48 \mathrm{~h}$ & $1.56^{\mathrm{a}} \pm 0.05$ & $1.61^{\mathrm{a}} \pm 0.07$ & $1.60^{\mathrm{a}} \pm 0.08$ \\
$96 \mathrm{~h}$ & $1.55^{\mathrm{a}} \pm 0.06$ & $1.63^{\mathrm{a}} \pm 0.08$ & $1.62^{\mathrm{a}} \pm 0.08$
\end{tabular}

Means in the same row, followed by same letters, do not differ $(\mathrm{p}>0.05)$ by Tukey's test.

Table 2. Average (mean \pm standard deviation) of forelimbs stumbling according to the evaluation times (hours) in the analysis of the shoeing adaptation period in horses subjected to three different shoeing conditions

\begin{tabular}{cccc}
\hline Evaluation times & \multicolumn{3}{c}{ Shoeing condition } \\
\cline { 2 - 4 } & Flat Standard & Toe elevation & Heel elevation \\
\cline { 2 - 4 } & \multicolumn{3}{c}{ Stumbles } \\
\hline $0 \mathrm{~h}$ & $0.33^{\mathrm{a}} \pm 0.52$ & $1.67^{\mathrm{a}} \pm 1.97$ & $0.33^{\mathrm{a}} \pm 0.52$ \\
$48 \mathrm{~h}$ & $0.17^{\mathrm{a}} \pm 0.41$ & $0.67^{\mathrm{a}} \pm 1.21$ & $0.33^{\mathrm{a}} \pm 0.52$ \\
$96 \mathrm{~h}$ & $0.33^{\mathrm{a}} \pm 0.52$ & $0.50^{\mathrm{a}} \pm 0.84$ & $0.17^{\mathrm{a}} \pm 0.41$
\end{tabular}

Means in the same row, followed by same letters, do not differ $(p>0.05)$ by Tukey's test.

In the present study, no statistical difference was found between the evaluation times. Our results indicate that horses are able to adapt to the new shoe condition immediately after the procedure. The qualitative results did not appear statistical difference between the days evaluated, nevertheless, immediately after elevation of the toe, two animals were observed to be dragging their toes and not supporting the sole on the rolling mat of the treadmill. Table 2 shows the mean value and the high standard deviation $(1.67 \pm 1.97)$ indicating this condition for this horses. According to Bowker et al. (1993), the proprioceptive receptors of the hoof are more concentrated near the heels and this finding may explain the higher level of incoordination observed after elevating the toes compared to elevating the heels. For quantitative analyzes (stride length) this effect was minimized because the image cutting and synchronization allowed us to choose six paces with apparent harmony and synchrony.

According to Chateau et al. (2004), performing a movement analysis of the locomotive system of horses immediately after shoeing is not recommended because the animal needs five days to adapt to the new shoe. However, based on the statistical results for quantitative and qualitative analysis of movement, our results revealed that the animals were able to adapt to the new shoeing condition immediately after the procedure.

\section{CONCLUSION}

With this study, one can conclude that elevating the toe or heel by six degrees do not generates discomfort during locomotion, therefore, horses are able to return to a regular exercise or training routine immediately after shoeing. 


\section{REFERENCES}

Adams O.R. 1994. Andaduras naturais e artificiais, p.875-88. In: Stashak T.S. (Ed.), Claudicação em Equinos segundo Adam's. Roca, São Paulo. 943p.

Back W. 2001. Intra-limb coordination, p.95-134. In: Back W. \& Clayton H. (Eds), Equine Locomotion. W.B. Saunders, London. 383p.

Barrey E. 2001. Inter-limb coordination, p.77-94. In: Back W. \& Clayton H. (Eds), Equine Locomotion. W. B. Saunders, London. 383p.

Barros R.M.L., Brezikofer R., Leite N.J. \& Figueroa P.J. 1999. Desenvolvimento e avaliação de um sistema para análise tridimensional de movimentos humanos. Revta Bras. Engenharia Biomédica 15:79-86.

Bertone A.L. 2003. Gait analysis for the quantification of lameness, p.222225. In: Ross M.W. \& Dyson S.J. (Eds.), Diagnosis and management of lameness in the horse. W.B. Saunders, St Louis. 1140p.

Bowker R.M., Brewer A.M., Vex K.B., Guida L.A., Linder K.E. \& Sonea I.M. 1993. Sensory receptors in the equine foot. Am. J. Vet. Res. 54:18401841.

Chateau H., Degueurce C. \& Denoix J.M. 2006. Three-dimensional kinematics of the distal forelimb in horses trotting on a treadmill and effects of elevation of the heel and toe. Equine Vet. J. 38:164-169.

Clayton H. 2004. Gait characteristics, p.163-193. In: Clayton H. (Ed.), The Dynamic Horse: A biomechanical guide to equine movement and performance. Sport Horse Publication, Mason. 265p.
Eliashar E., Guigan M.P., Rogers K.A. \& Wilson A.M. 2002. A comparison of three horseshoeing styles on the kinetics of breakover in sound horses. Equine Vet. J. 34:184-190.

Figueroa P.J., Leite N.J. \& Barros R.M. 2003. A flexible software for tracking of markers used in human motion analysis. Comput. Meth. Progr. Biol.72:155-165.

Leach D. 1938. Biomechanical considerations in raising and lowering the heel. Proc. 28 ${ }^{\text {th }}$ Annual Convention of the Americans Associations of Equine Practioners, p.20-30.

O'Graddy S.E. \& Poupard D.A. 2003. Proper physiologic horses shoeing. Vet. Clin. Norh Am., Equine Pract. 19:333-351.

O'Graddy S.E. 2008. Basic farriery for the performance horse. Vet. Clin. North Am., Equine Pract. 24:203-218.

Parks A. 2003. Form and function of the equine digit. Vet. Clin. North Am., Equine Pract. 19:285-307.

Ross M.W. 2003. Conformation and lameness, p.15-81. In: Ross M.W. \& Dyson S.J. (Eds), Diagnosis and Management of Lameness in the Horse. W.B. Saunders, St Louis. 1140p.

Silva M.G.A., Martins C.B., Gomide L.M.W., Albernaz R.M., Queiroz Neto A. \& Lacerda Neto J. C. 2009. Determinação de eletrólitos e gases sanguíneos venosos em equinos destreinados submetidos a exercício máximo e submáximo em esteira rolante. Arq. Bras. Med. Vet. Zoo. 61:10211027. 